József Kandikó - Judit B. Varga

\title{
A Successful Programme to Help Hungarian Intellectuals Beyond the Border
}

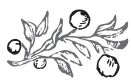

\section{Summary}

Collegium Talentum, a support system for Hungarian talent beyond the border, has been operating since 2011 in the Carpathian Basin. The aim of the programme is to train young researchers to become scientifically well-grounded specialists by both national and European standards, to attract fresh blood to academic institutions, and to inspire them to convey national cultural values in addition to having a scientific career. The programme supports the progress of 90 young doctoral students, thus significantly contributing to mitigating the crisis caused by the lack of intellectuals beyond the borders. More than 300 intellectuals from all over the Carpathian Basin have been involved in the programme to date, and a successful network has been organized of professors and researchers committed to national values.

Keywords: crossborder support, young researchers, Carpathian Basin

Collegium Talentum students from beyond Hungary's border gathered for a celebration on 11 June 2016 in the Auditorium of the Hungarian Academy of Sciences. In the 2015-2016 academic year, 24 out of 74 active Collegium members came to receive certificates attesting to their performance during the three-year support period, and complimentary copies of the volume of studies entitled Smart Net 2016, containing the research results of graduate Collegium members, published for the third time.

Dr József Kandikó, college professor, Edutus College (kandiko.jozsef@ edutus.hu), Dr Judit Berta VArga, historian and training organizer, Edutus College (collegiumtalentum.oktatasvezeto@edutus.hu). 


\section{József Kandikó - Judit B. Varga: A Successful Programme to Help Hungarian...}

Collegium Talentum was established as an organization in the summer of 2010, based on a decision of the Senate of the College of Modern Business Studies, and set out on its activities using funds contributed by Bethlen Gábor Alap Zrt in January 2011. Its mission, modelled on the former Selye János College, is to provide support to and form a community of the Hungarian scientific and educational elite on territories detached from the main body of the nation. The goal was to patronize the thirty most talented out of 30,000 Hungarian students living and studying beyond the borders, and to provide them with international-level talent management for three years. This system, which is built on the principle of "invisible fraternity", is based on personal specialised tutoring, offers extensive education and financial support, and has a unique role in the formation of communities beyond the borders. Our mission is to set up academic teaching staff with the ability to teach in Hungarian for the Hungarian-speaking tertiary educational institutions that have been established in neighbouring countries.

Its political background is provided by a document published by the Ministry of Public Administration and Justice in 2011 and entitled Strategic Framework for a National Policy (KIM, 2011), which stipulated the following in relation to talent management in section 3.2.4: "The fulfilment of the role of young people with a high standard of knowledge can contribute greatly to the cultural and economic potential of Hungarians. For this reason, special attention must be paid to talented young people. They should be identified, selected and educated within the framework of various special and targeted programmes. Collegium Talentum is an important example of just such a talent management programme that aims to support outstandingly talented Hungarian youth abroad and to offer them specialised knowledge of a high standard that will help them excel in international academic life."

In the past five and a half years, Collegium Talentum has become a stronghold of Hungarian intelligentsia growing up abroad, connecting young Hungarian talent being developed in five countries with Hungary and with renowned researchers and professors in various academic fields. The fundamental goal is to inject fresh blood into Hungarian intellectuals abroad, and strengthen the academic teaching elite beyond the borders by opening up prospects to set research careers in motion. To this end, Collegium Talentum trains young people who are interested in the transmission of national values in addition to their professional careers, to become academically well-grounded and well-informed at a national and international level. The programme facilitates the co-ordinated professional development of young researchers, thus contributing to the solution of a crisis in the Hungarian elite abroad. This also means that Collegium Talentum has assumed a role in various master's degree programmes (or from the 5 th year in combined degrees) for native speakers of Hungarian, and in the preparation of postgraduate students for their doctoral degrees. In the framework of the three-year support programme, personal tutors are selected from among the professors of their respective fields to help the Collegium members in their research. There is no differentiation between disciplines during selection. The members of the Collegium are forged into a strong community and into a smart network for the Carpathian Basin in quarterly train- 
ing courses that strengthen their national identity and solidarity. Collegium Talentum creates the organizational and infrastructural conditions for the Collegium members to become, alongside their university studies, members of a community building a national and academic network operating at a high standard.

Over the past five years, Collegium Talentum has fulfilled this goal. Its main achievement has been to set up a platform for young teachers and researchers in the Carpathian Basin where post-graduate history students from Oradea and Uzhgorod, microbiologists from Cluj and Bratislava, ethnographers from Szeklerland and Slovakia, or mathematicians from Vojvodina and Cluj can meet, conduct debates and encourage each another. In addition to strengthening the Hungarian identity and national connectedness of youth in Slovakia, Subcarpathia (Zakarpattia Oblast in Ukraine), Transylvania in Romania and Vojvodina in Serbia, the Collegium Talentum support programme also broadens the Hungarian scientific and social elite by encouraging them to stay in their home countries. It is already evident that young teachers and researchers who have done their doctorates with help from Collegium Talentum are present in all higher education institutions of the neighbouring countries. Selye János University, also supported by the Hungarian state, Sapientia EMTE, the Rákóczi Ferenc II Hungarian College of Subcarpathia at Beregovo and the College of Subotica are not the only examples. Babess-Bolyai University, the Medical and Pharmaceutical University of Târgu Mures, the Constantine the Philosopher University of Nitra, the Comenius University of Bratislava, the National University of Uzhgorod, and the Novi Sad University all have teachers who were or have been supported by Collegium Talentum.

In the period between 2011 and 2015, 152 students, primarily PhD candidates, were granted Collegium Talentum support at various tertiary institutions in the Carpathian Basin, and we continue to have close and live relationships with them today, as they remain active Collegium members, many of them as members of the increasing Alumni network. Fifty four of the 152 members admitted to the Collegium have completed the full three-year cycle, and 74 students can be considered as active Collegium members. Twenty two members left the Collegium early, for professional or personal (health or family-related) reasons. One-third of the graduated Collegium members have already been admitted to the Hungarian Academy of Sciences as external members.

\section{Collegium Membership}

Collegium Talentum may have a maximum of 90 persons at a time (in three classes, 30 persons per class), plus one tutor per Collegium member. The talent management programme offers support to the members admitted to the Collegium for six terms. No postponement is allowed. During this period, the Collegium member is paid monthly stipends and is earmarked other financial support, while the tutor is paid personal support and participates in three-day training courses once a quarter.

A tutor is a recognised teacher of the institution in the academic field the student is engaged in, supervising the Collegium member in the first year of the grant pro- 
gramme, although in the second year, a different professional advisor, or tutor, must be selected from another institution. Both the first tutor and the Collegium management provide help in the selection. Tutors may be replaced only once in the three subsidised years. One tutor can supervise no more than two Collegium members at a time.

Work is performed, and the stipend is paid, on the basis of a grant agreement concluded with the Collegium member and the tutor for a term and setting out the tutor's obligations and rights. On re-contracting, once per term, the Collegium member must declare that he or she is not paid any other state grant from Hungary. If the Collegium member's legal relationship with his or her university is terminated (for reasons of graduation or dropout), the Collegium membership is also terminated. Thus, despite the fact that a new class of 30 students is started every year, the planned headcount of 90 is not usually filled, with the average headcount being between 70 and 80 students.

Regional rates approximately correspond to the ratio of Hungarians, with the exception of Subcarpathia. This is, however, understandable, as the latter region offers the lowest number of opportunities for learning, and especially for doing one's doctoral studies, in Hungarian. At the same time, this region has recently been the special target of various kinds of support to keep people in their homeland. Unfortunately, the unrealistically low and unsuitable ratio of natural sciences is due to the decadelong general decline of interest in natural sciences in the reviewed areas.

Figure 1: Distribution of Collegium Talentum members by region, 2011-2015

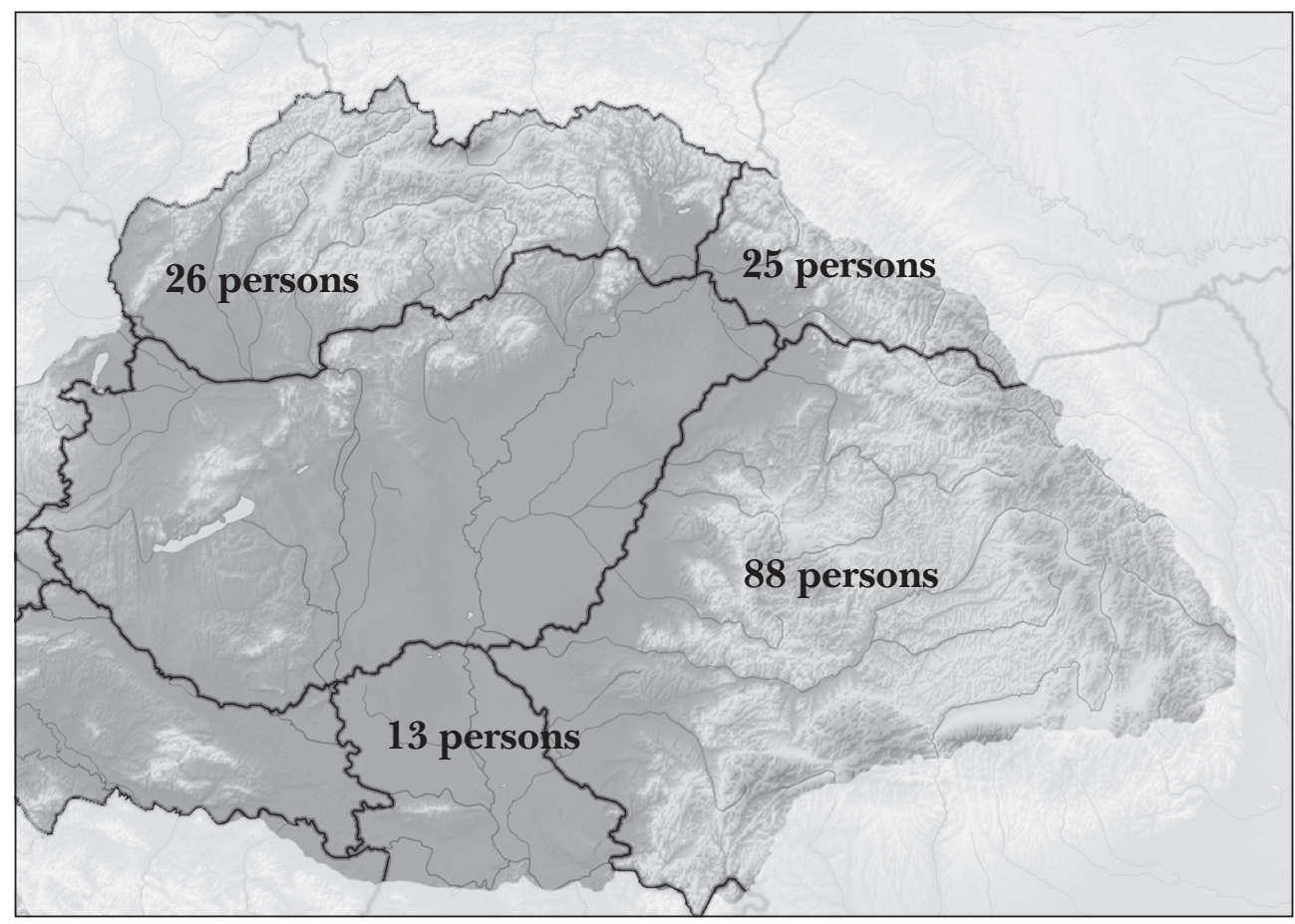

Source: Annual reports of Collegium Talentum 
Figure 2: Distribution of Collegium Talentum members by academic discipline, 2011-2015

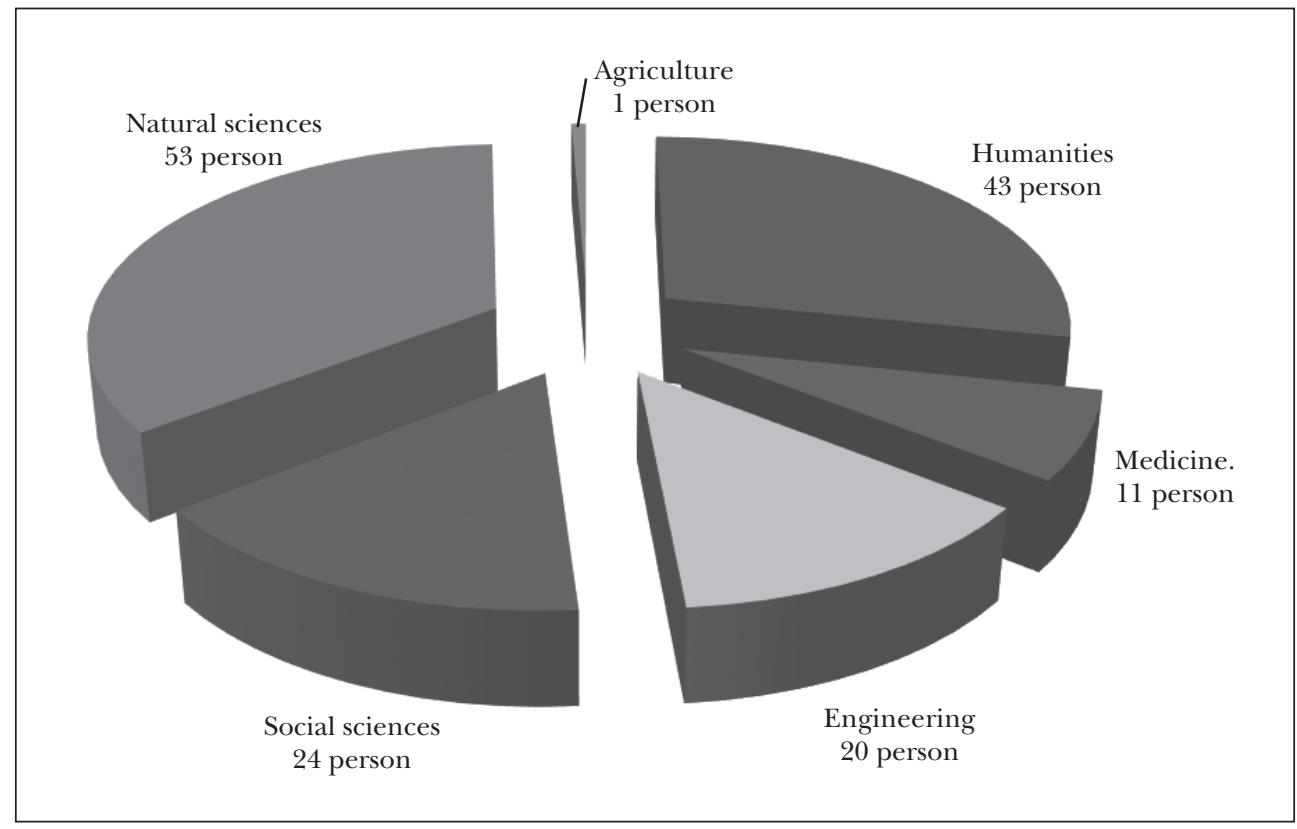

Source: Annual reports of the Collegium Talentum

If students' personal tutors are also taken into account, in five years altogether total of 304 persons have established long-term contact with this form of talent management, which also serves specific national policy goals, organized by Collegium Talentum and through the Bethlen Gábor Foundation. To this number can be added more than two hundred lecturers, trainers and professional supervisors who have met the organisation at training courses and various programmes. Thus, the scope of Collegium Talentum already covers more than five hundred Hungarian intellectuals in the Carpathian Basin.

\section{Collegium TAlentum grants}

\section{Stipend}

A Collegium member is paid HUF 72,000 per month for 10 months in per academic school (within the framework of two semester-long contracts), which may only be received personally, in cash, during the mandatory quarterly training courses. (Personal payment in cash is required to guarantee the Collegium members' participation in the mandatory training courses). In return for the stipend, the Collegium member is expected to finance his or her travels to mandatory training courses held in Hungary, and purchase the research and experimental materials and smaller equipment and books required for his or her research. 
József Kandikó - Judit B. Varga: A Successful Programme to Help Hungarian...

The tutor is also paid a stipend of HUF 50,000 per month for 10 months per year within the framework of semester-long contracts. Tutors receive the stipend by bank transfer.

\section{Professional tutorial help}

The most effective help to a Collegium member in his or her professional progress is given by a tutor. The tutorial system includes customised activities that supplement the scholarship student's regular studies. The Collegium member undertakes to prove their aptitude through their learning outcomes and academic progress.

The tutor undertakes to direct the student and call them to account for the work done and progress made during the semester according to the criteria determined by the management of Collegium Talentum and the work schedule developed jointly with the Collegium member. It is especially important for the tutor to support the Collegium member's publications and professional integration. For this purpose, the tutor calls the Collegium member's attention to conferences held in Hungary and abroad and encourages them to participate. The tutor must pay special attention to the drafting of the student's publications, proofread them and actively promote their publication. The tutor must carry out personal tutoring at least twice a month. Tutoring can also be performed electronically, in which case the email messages must be archived.

A tutor must have an academic specialisation, must be a recognised representative of their academic field, and be a full-time employee or retired former employee of a research institution or educational institution in Hungary or abroad.

At the end of each semester, the tutor must make a written report of the grantee's performance and progress (tutor's report), giving an opinion on further support for the grantee. In relation to this, the tutor is entitled to seek information at any time about the Collegium member's work as defined in the relevant work schedule. If the Collegium member fails to properly cooperate or make appropriate progress, the tutor must inform the Collegium Talentum management of this fact.

\section{Sponsored conference participation}

Collegium Talentum encourages its members' participation in conferences held in Hungary or abroad. If the Collegium member delivers a lecture or presents a poster at an international conference that they have registered for, and thus increases the number of their documented publications, they may be granted financial support from Collegium Talentum within the limits set and based on a previous written application.

\section{Encouragement to learn foreign languages}

Collegium members are expected to make continuous progress in two different foreign languages (other than the official language of their home country) during the period of the grant. The Collegium member must document their continuous lin- 
guistic progress once per semester in a report, and must advance to the next level within two semesters, providing evidence with a language examination certificate. Collegium Talentum reimburses the costs of a successful language examination in cash against an invoice. If the Collegium member fails to make progress in language examination levels within two semesters, only a reduced stipend will be paid to them until they produces the appropriate language examination certificate. Following the production of the language examination certificate, the member is again entitled to a full stipend, and has two semesters to fulfil the next level of language examination.

\section{Obligation to compile a work plan and a report}

Collegium members must submit a self-development and research plan for each contracted semester, and at the end of each semester they must make a progress report following the criteria specified by the management of Collegium Talentum. The semester work plan must include the expected results in specific terms, whether in written or oral form. In their work plan for the semester, the Collegium member must undertake to appear at a minimum two specialist public events and provide demonstrable results, with proof in a progress report.

The progress report may include more or other achievements than those in the work plan, but a measurably reduced outcome is unacceptable. In this case, the Collegium member is first warned and their stipend reduced for the next semester, and if it occurs a second time then the Collegium member's legal entitlement to a grant is terminated. Every semester the professional management of Collegium Talentum evaluates the Collegium member's performance on the basis of the progress report for the semester and the written tutorial report, and takes it into account for the next semester's contract.

\section{Mandatory quarterly training}

Collegium Talentum's activities and operations are intended to continue Hungary's tutorial tradition, which is exceptionally rich even by European standards. In this tradition, a "collegium", or board, is an independent intellectual workshop, an institution that passes on the most modern intellectual achievements, and artistic and educational values. Training courses held quarterly forge Collegium members into a strong community by strengthening their national identity and solidarity. In order to achieve this, a feature of the talent and elite training programme of Collegium Talentum is that Collegium members must take part in a three-day training programme. In order to encourage and enforce personal participation, regular financial support, conference participation fees and language examination support are paid, and personal discussions and evaluations based on individual work plans and reports are also held on these occasions.

In the course of attending to the complex duty of talent management, we endeavour to develop outstanding professional skills and creative thinking and a commitment to and motivation towards the selected academic field and community. For this 


\section{József Kandikó - Judit B. Varga: A Successful Programme to Help Hungarian...}

reason, we provide an environment at mandatory training courses where the participants can feel at home professionally, personally and as Hungarians.

Collegium members cover many different academic areas, and they learn the process of thinking collectively. It is an advantage that these young people come from the most varied institutions of higher education and have different social backgrounds, and for this reason our concept includes encounters and familiarisation with many different opinions, the acquisition of a culture of debate, and the education of intellectuals sensitive to one another and to social problems. We endeavour to make our members the primary beneficiaries and realisers of an interdisciplinary approach.

It is seen as a fundamental value in our educational concept that during six semesters spent in the tutorial scheme, our members acquire positive behavioural patterns, in addition to high standards of professionalism, which help them achieve success in the institutions of their home country, and make them leaders and active public figures capable of responsibly influencing decisions. During the compilation of the training content, an additional objective is to familiarise them with the discourses that academia is most interested in and with the most recent competitive areas, to provide them with access to and the opportunity to work in these areas, if possible, during the period of their membership. In addition to ensuring personal academic performance, which is guaranteed by the relationship between the tutor and the tutored member, an emphasis is placed on cooperative skills and personal development.

The following topics are of particular importance; they determine the content framework of the courses, which always organized on an individual basis with specialist trainers some of whom are constant but most of whom are frequently changed:

- Coaching, development of communication skills, self-understanding, and community building;

- Hungarian national policy, national memory, national holidays, Hungarian culture, and famous Hungarian role models;

- Local values and tourist sights, new exhibitions, and Hungarian customs;

- Learning policy, the history of knowledge, Hungarian scholarship abroad, and academic communication;

- Pedagogy, the history of education, and educational methodology and techniques.

Collegium Talentum provides lecturers, trainers and the technical conditions for training (accommodation, catering, tickets to and participation fees for certain programmes, and the costs of travel to programmes). Collegium members must pay the costs of their travel to and from the training site. At the end of the training, Collegium member students evaluate the programme. The Collegium Talentum management takes their experiences into consideration during the organisation of subsequent programmes.

Supported Collegium members must participate in the collective training courses announced, at the latest, at the beginning of Collegium semesters. Unless justified on health grounds by a doctor, failure to fulfil the above entails termination of the stipend, in terms of the per capita costs of training. The stipend is not paid in the case of 
absence without leave, and this amount may not be received subsequently or through a proxy. The management takes absence without leave or early leave into account in the semester performance evaluation.

\section{Winter Academy}

The Winter Academy, which is usually held in the first calendar quarter, brings together the members of all three years. This is a 4- to 6-day excursion in which about half the active Collegium members participate by registering beforehand. Destinations include the memorable sites and university towns of Hungarian history. As the participants spend several days together in a more informal programme, relationships become closer, and at each location the Collegium members are familiarised with the different social, educational and living conditions of their fellow Hungarians, as well as the beauties of nature and the old Hungarian cities and towns of the Carpathian Basin. (So far, locations have included: Novi Sad, Senta, Subotica, Miercurea Ciuc, Cluj Napoca, Oradea, Bratislava, Banská Štiavnica, Trnava, Szeged, Pécs and Gyôr). At these locations, the programme is enhanced by sightseeing, university visits, the presentation of research sites and personal meetings with local tutors. The full travel and accommodation costs of the Winter Academy, all tickets, admission and guide fees, and the costs of organized meals are borne by Collegium Talentum.

\section{AGHIEVEMENTS DURING THE FIVE YEARS OF OPERATION}

\section{Publications}

The most important measure of academic progress (in general agreement with the requirements of doctoral schools) is the number and quality of publications. A publication may be printed (reference book, a chapter in a book, an article, a review, a published study or abstract, or a poster presented at a conference) or an oral publication (at an international specialist conference, a conference in one's home country, during a workshop debate, or a public lecture at an event, including participation in a programme of the Students' Scientific Association corresponding to the Collegium member's level). As the Collegium trains and manages elite and talented individuals, the expected level of achievement must be higher than the general research and publication requirements of a doctoral school. The expected date and place of the publication must be specified in the statement, and the delivered or printed publication must be specified in the progress report according to the official rules for journalistic references.

Over the past five years, Collegium members have delivered 427 lectures at academic conferences, 34 of them at significant international conferences. These were published in the programmes and in the publications of the relevant conferences, and increased the lists of the lecturing students' scientific achievements. Every year several Collegium members participate in the International Students' Associations 
József Kandikó - Judit B. Varga: A Successful Programme to Help Hungarian...

Conferences organized by the universities of the individual regions and at tests specifically organized for doctoral candidates.

The number of reference books, chapters in reference books and publications in specialist journals has been 535. These have been published in large numbers in noted journals devoted to various academic fields, but some of them are complete reference books, chapters or educational materials. Half of the publications were in a foreign language, for the most part in English. The aggregated impact factor of the articles published by our Collegium members in scientific journals exceeds thirty.

\section{Role in science communication}

Each Collegium member is obliged to take part in conferences, workshop discussions and other events organized by Collegium Talentum where they must deliver a lecture, make a report or lead a discussion, and are required to compile the publication requested by the Collegium management for the publicity of the organization's results.

Conferences on the occasion of the Celebration of Hungarian Science

One of the autumn training courses is held during the Month of Hungarian Science in November. In the framework of the training, Collegium Talentum organizes public conferences to introduce first year members, and also invites the tutors along ${ }^{1}$. Lectures are followed by professional questions in the framework of a public conference, and lecturing and presentation techniques are discussed at the subsequent workshop.

\section{Novel Science Communication Projects}

Every academic year, Collegium Talentum organises publication opportunities for senior student members of the Collegium to present the findings of research conducted during the period of the grant. This is an opportunity for the students to obtain experience in the creation and use of innovative academic communication instruments. Thus, posters or science slams may be presented with the knowledge of the Collegium members' academic groups and topics. Competition improves the programme. The management announces in advance the conditions and method of judging science communication and the awards.

Poster exhibition and competition

In 2013, for the first time in the history of Collegium Talentum, a poster exhibition and competition was organized. The posters of 46 senior Collegium members were exhibited in the House of Hungarians. This was the very first occasion in the life of the Collegium that the professional results that have been achieved were presented to scientific circles and the wider public in the form of a major event. The other ob- 
jective of the poster exhibition and competition was to encourage the students newly admitted to the Collegium and to give them an example of scientific communication to be used in their research career ${ }^{2}$. From the moment the idea of a poster competition arose, we gave information on the competition and the process and techniques for creating posters, and provided consultation opportunities for the Collegium members. They were required to place professional material that had been proofread by their tutors into a predetermined printer's frame. The posters were printed for the exhibition, but an A4-size flyer was also made of every poster with the Collegium member's biography on its reverse side. This also served as the press material for the event, and was used for wider awareness raising. ${ }^{3}$

Science Slam

The real homes of science slams are the stages in theatres, clubs and entertainment halls, where new scientists can explain the meaning and application of their research to non-specialists. The first Science Slam competition was organized in 2008 in Darmstadt. It has been so successful in Germany that it now has a central organizational centre and seats must be reserved for the biggest competitions. The first European Science Slam was organized in Copenhagen in June 2014.

In the - for the time being more moderate - Hungarian version young biologists, historians, men of letters, linguists, psychologists, architects, mathematics teachers, philosophers and geographers spoke to the general public about their amateur achievements, in creative stories filmed using modern IT tools. These short films were shown on 20 November 2015, during the Celebration of Hungarian Science, at the Edutus College.

\section{Workshop Discussions}

In recent years two scientific workshop discussions were held with the Intellectual and Infrastructure Conditions of Hungarian-language Scientific Research in Other Countries. The first one was organized in Cluj jointly with the Babes-Bolyai University and the Cluj Academic Committee, and the second one in Beregovo, in cooperation with the Rákóczi Ferenc II Hungarian College of Subcarpathia. Collegium Talentum introduced itself and gave information at the BB University of Cluj, Sapientia EM University of Targu Mures, the Constantine the Philosopher University of Nitra in Slovakia, and at the Selye János University, and participated in the Summer Open University held at Bálványos.

\section{Smart net}

For graduates - in general to close the six-semester support programme - Collegium Talentum compiles books of reviewed specialized articles about Collegium members' research topics or any one of their results, and presents them during the degree ceremony. The academic János Péntek, then Chairman of the Cluj Academic Committee made a review of the first volume published in 2014: "Undoubtedly, Collegium Talentum can 
have a significant role in mitigating two major problems of Hungarian science beyond the borders. One of them is the generational shortage that started in the three or four decades preceding 1990. A new generation of teachers and researchers has grown up and has found relevant positions in the past two and a half decades. Now CT members can ensure its continuity and natural order, and can make up for the still significant gaps that exist. And, as seen on the basis of the book, this is what they are doing. The other problem, which is more difficult to solve, is the closed and clannish attitude of staff, as a result of previous isolation, unregulated operation due to the lack of government control, sub-critical research headcounts and lack of institutions. This entails insufficient respect for professionalism and competence, and due to a lack of a constant dialogue and criticism, the genuine order of values cannot be set up. This makes young people's integration more difficult. CT's "net" works against this, representing major progress in developing common training and research in the Carpathian Basin. This is the elimination of borders the Academy also endeavours to achieve using its grant scheme, system of relationships and prestige" (Péntek, 2015). Additional volumes were published in 2015 and 2016, and were distributed to university libraries all over the Carpathian Basin.

\section{NEW AND RETIRED COLLEGIUM MEMBERS}

\section{Admission procedure}

Following the negotiations and contract conclusions that guarantee annual financing, which take place generally in spring, Collegium Talentum requests applications for admission and support. The invitation is published on posters placed in higher education institutions in neighbouring countries and in student, youth and professional organisations, online in the social media, and through personal communication in the form of roadshows.

The chairman and the educational director of Collegium Talentum evaluate the materials submitted in writing, with the involvement of external experts if necessary. Approximately half of the applicants are invited for an interview with an academic committee of five, according to the groups of academic disciplines announced in the tenders. In early October, Collegium Talentum enters into a grant contract with the thirty persons accepted, providing that they can prove their current student status and submit their first semester plan by the deadline.

\section{Degree ceremony}

One day during the June training programmes, a degree ceremony is held for the graduating members of Collegium to conclude the grant period. On this occasion, those who have obtained their doctoral degrees and fulfilled their professional obligations are also granted a certificate even if they have not been paid support for six semester. This event also includes the awarding of the Prima Prize, founded by Collegium Talentum for the young person coming from a neighbouring country who 
excels in knowledge and humility as a researcher, and also represents the mission objective of Collegium Talentum, which is to realise the noble task of staying in one's home country to build and strengthen Hungarian communities abroad.

\section{Alumni system}

A Collegium member who has concluded the grant period becomes a member of the Alumni organization if, in alignment with the mission of Collegium Talentum, they perform professional work in their home country. By signing the letter to join the Alumni organization, former Collegium members agree to abide by the rules of engagement (e.g. assume assignments to popularize Collegium Talentum), and may participate in Collegium Talentum's Alumni grant programmes and benefits (events, Collegium programmes, partial support for lectures at international conferences etc.).

\section{FEEDBACK}

The feedback received from Collegium members, whether spontaneous or, occasionally, requested by the management in relation to an event or a programme, provides an impression of the outcome and benefits of the three-year talent management. The stipend paid by the Collegium, usually directly to its student members, has enabled them not to have to take employment just to satisfy their material needs, or to secure the required supplementary income through less time-consuming jobs. Thus, they have been able to devote the majority of their time and energy to research. The majority of Collegium members assign great importance to the Collegium's role in developing the mind and in community building, highlight the opportunities and achievements, and have good memories of the programmes aimed at strengthening Hungarian identity and national solidarity.

In early 2016, we were informed that the Office of the Minister of State for National Policy was planning to suspend and reform the current operational form of the five-year-old Collegium Talentum. As currently, in the autumn of 2016, we still do not have new information in any form whatsoever on the programme's operation, we were unable to convey encouraging news on 21-23 October to the thirty-two former Collegium members who gathered in Budapest for the Alumni programme.

At the end of 2016 the Sapientia Hungariae Foundation was nominated by the Office of the Minister of State for National as the new organizer of the Collegium Talentum. On the 13th March 2017 the Board of Trustees decided the first steps of the continuation of the support system Collegium Talentum still in the first half of 2017.

\section{Notes}

1 The following are a few illustrative examples of the topics discussed in the past few years. In 2012: Beáta Grabovac, University of Novi Sad: Emotional Contexts of Monolingualism and Bilingualism in Vojvodina; Sándor Bulcsú, BBTE: Symmetry in Inverted Stock Exchange Statistics; in 2013: Vas Krisztina, MOGYE: Resistance 
József Kandikó - Judit B. Varga: A Successful Programme to Help Hungarian...

Problems in the Case of Staphylococcus Aureus Strain; Áron Tótös, University of Oradea: Political Evaluation of Prostitution in Hungary in the Second Half of the 19th Century; László Gogolák, University of Novi Sad: Application of Wireless Sensor Networks Among Industrial Conditions; In 2014: Júlia Makkai, BBTE: Young Ladies in Transylvania - The Pink Fable of Transylvania in a Regional Reading; Jolán Turóci, National University of Uzhgorod: From Atoms to Quarks.

2 Besides major national radio and television channels (MTVA, MR1-Kossuth Radio, Echo TV, Lánchíd Radio), internet forums (the National Talent Promoting Committee of MTA, tehetseg.hu) were also interested in the research topics shown on the posters, and several newspapers reported on them in Hungary and abroad.

3 The posters can be viewed on the website of Collegium Talentum. www.collegiumtalentum.com/index. $\mathrm{php} /$ rendezvenyeink/poszter-konferencia/95-a-collegium-talentum-poszterverseny-eredmenyei

\section{REFERENCES}

KIM (2011): Magyar nemzetpolitika. A nemzetpolitikai stratégia kerete. [Hungarian National Policy. Strategic Framework for a National Policy], Budapest.

Péntek, János (2015): Talentumok az „intelligens hálóban” [Talent in the "Smart Net”.] Magyar Tudomány, no. 6 . 